\title{
Depressieklachten onder Turkse en Marokkaanse Nederlanders van de eerste generatie
}

De rol van beperkte integratie en beheersingsoriëntatie

\author{
Ellen Bekker \& Maurice Gesthuizen
}

MEM 90 (3): 275-305

DOI: 10.1557/MEM2015.3.BEKK

\begin{abstract}
Summary
Depressive symptoms among Turkish and Moroccan migrants in the Netherlands: the impact of disintegration and locus of control

Previous research showed that especially Turkish and Moroccan migrants in the Netherlands run a higher risk of experiencing symptoms of a depressive disorder than indigenous Dutch people. In this study we aim to explain why some Turkish and Moroccan migrants experience these symptoms of depressive disorder to a higher degree than other members of these groups. We used cross-sectional data from the Dutch Life Course Study (Nederlandse Levensloop Studie). Although one indicator of social disintegration, experienced loneliness, appeared to be the most important predictor for symptoms of a depressive disorder among these migrant groups, indicators of economic and psychological disintegration were also clear predictors for these symptoms. However, psychological disintegration, which we theorized to be the final stage of integration and therefore serves as a mediator, was unable to explain the relationships of economic and social disintegration with depressive symptoms. Moreover, taking the locus of control into account, appeared to provide important nuances for interpreting these effects: for those who experience more control over their lives, disintegration in the domains mentioned is less strongly linked with depressive symptoms than for those who experience less control over their lives.
\end{abstract}

Keywords: migrants, depressive symptoms, disintegration, locus of control 


\section{$1 \quad$ Inleiding}

Voor individuen is gezondheid een belangrijke, zo niet de belangrijkste indicator voor de kwaliteit van het leven (Kooiker, 2011). Bovendien zijn de maatschappelijke kosten van ongezondheid groot. Zo kosten psychische problemen, zoals depressieklachten, de Nederlandse maatschappij jaarlijks 20 miljard Euro (OECD, 2014). Om de negatieve gevolgen van depressieklachten voor individuen en de kosten voor de maatschappij te kunnen bedwingen, is onderzoek naar de oorzaken van depressieklachten van groot belang. In deze studie richten wij ons op depressieklachten onder Turkse en Marokkaanse migranten. Bekend is dat zij een bovengemiddeld risico lopen op het ervaren van geestelijke problemen (De Wit et al., 2008; Selten et al., 2012). Depressieve symptomen komen ongeveer twee tot vier keer zo vaak voor onder respectievelijk oudere Marokkaanse en Turkse Nederlanders dan onder autochtone ouderen (Van der Wurff et al., 2004). Ook migrantenjongeren kampen vaker met depressieklachten dan autochtone jongeren (Gijsberts \& Dagevos, 2009; SCP, 2002). In dit onderzoek richten we ons op verschillen in depressieklachten binnen de groep van Turkse en Marokkaanse Nederlanders van de eerste generatie. We beantwoorden de vraag waarom sommige migranten meer depressieklachten ervaren dan anderen en belichten de rol van economische, sociale en psychische restricties (beperkte integratie) en beheersingsoriëntatie. ${ }^{1}$

We pogen op een aantal punten verbetering te boeken op voorgaand onderzoek. Ten eerste is er onduidelijkheid over de verklaring van verschillen in depressieklachten binnen migrantengroepen. Uit onderzoek dat allochtonen vergelijkt met autochtonen blijkt dat, rekening houdend met diverse mogelijke oorzaken, verschillen in depressieklachten tussen migranten en autochtonen prominent aanwezig blijven (Aichbercher et al., 2010; Missine \& Bracke, 2012; Van der Wurff et al., 2004). Verschillende auteurs zoeken de verklaring hiervoor in de mate van integratie van migranten in diverse domeinen van de ontvangende samenleving (Berry, 1997; Koneru et al., 2007) en daarmee bij de hulpbronnen die zij tot hun beschikking hebben. Een sterke mate van economische, sociale en psychische integratie - maar met behoud van eigen identiteit - zou het beste zijn voor het psychisch welbevinden van migranten (Berry, 2005). Wij gaan na in hoeverre de mate van economische, sociale en psychische integratie in de ontvangende samenleving kan verklaren waarom sommige migranten meer depressieklachten ervaren dan andere migranten.

Ten tweede is het empirische verband tussen de vormen van integratie en depressieklachten tot op heden nog onduidelijk. Psychische integratie 
in de ontvangende samenleving - identificatie met de ontvangende samenleving, sociaal vertrouwen en vertrouwen in politieke instituties wordt gezien als het laatste stadium van integratie, dat pas tot wasdom komt als migranten ook meer toegang hebben tot de economische en sociale hulpbronnen in de ontvangende samenleving (Alba \& Nee, 1997). In deze studie stellen we daarom ook de vraag in hoeverre een beperkte psychische integratie als mediërend mechanisme kan fungeren om effecten van beperkte economische en sociale integratie te verklaren.

Een derde verbetering zoeken we in de rol van de beheersingsoriëntatie van migranten: hoe staan zij in het leven, of anders gezegd, hoe gaan zij om met de situatie waarin zij verkeren in de ontvangende samenleving? In onderzoek naar depressieklachten onder migrantengroepen is hiervoor nog nauwelijks aandacht geweest. Deze beheersingsoriëntatie ('locus of control') is een eigenschap van iemands persoonlijkheid, waarbij onderscheid wordt gemaakt tussen mensen die, kort gezegd, hun eigen leven als maakbaar beschouwen en mensen die het gevoel hebben geen controle te hebben over hun eigen leven (Rotter, 1954). Deze beheersingsoriëntatie bepaalt naar onze verwachting in hoeverre depressieklachten onder migranten zich ook daadwerkelijk manifesteren als gevolg van beperkte economische, sociale en psychische integratie. Als dit zo blijkt te zijn, dan is naast het stimuleren van integratie ook het bevorderen van een interne beheersingsoriëntatie onder migranten een mogelijke route om depressieve klachten tegen te gaan.

Etnische minderheden zijn in bevolkingsstudies vaak ondervertegenwoordigd en vormen een selectieve groep. In eerder onderzoek werden bijvoorbeeld alleen oudere migranten ondervraagd, migranten uit een bepaalde stad of slechts één etnische groep (Aichberger et al., 2010; De Wit et al., 2008; Van der Wurff et al., 2004). Een vierde punt van verbetering is dat we in deze studie geen selectieve groep Turkse en Marokkaanse migranten bestuderen (behoudens dat de maximale leeftijd 49 jaar is in de door ons gebruikte dataset) en beschikking hebben over een groot aantal migranten uit deze etnische groepen. Het gaat hiermee om eerste generatie migranten die in Nederland wonen, en in Turkije of Marokko geboren zijn. Hieronder vallen ook migranten die zijn meegekomen met hun ouders. Specifiek wordt gekozen voor Turkse en Marokkaanse Nederlanders omdat depressieklachten onder deze groepen vaker voorkomen dan onder andere etnische groepen (SCP, 2002). Daarbij maken we gebruik van gegevens afkomstig van de Nederlandse Levensloopstudie (NELLS; De Graaf, Kalmijn, Kraaykamp \& Monden, 2010). In deze vragenlijst zijn Turkse en Marokkaanse migranten oververtegenwoordigd. Bovendien bevat deze vragenlijst 
zestien items uit de Center for Epidemiologic Depression Scale (CES-D) waarmee depressieklachten onder deze etnische groepen betrouwbaar in kaart gebracht kunnen worden. Hierdoor kunnen de verklaringen voor (variatie in) het bestaan van depressieklachten binnen etnische minderheidsgroepen beter worden onderzocht.

De hoofdvraag van dit onderzoek luidt: 'in hoeverre gaan beperkte economische, sociale en psychische integratie samen met depressieklachten bij Turkse en Marokkaanse Nederlanders van de eerste generatie?'. De twee deelvragen luiden: 'in hoeverre wordt de invloed van beperkte economische en sociale integratie verklaard door psychische integratie?' en 'in hoeverre verschilt de invloed van beperkte economische, sociale en psychische integratie tussen groepen met een meer interne of meer externe beheersingsoriëntatie?'. Daarnaast wordt, naast geslacht, leeftijd, huishoudsamenstelling en opleidingsniveau, specifiek rekening gehouden met het ervaren van discriminatie. Uit voorgaand onderzoek blijkt dit van substantiële invloed te zijn op het rapporteren van depressieklachten (Virta, Sam \& Westin, 2004). In het vervolg van dit artikel leiden we toetsbare hypothesen af, presenteren we de resultaten van onze analyses, beantwoorden we de onderzoeksvragen in de conclusie en discussie en komen we terug op de wetenschappelijke en maatschappelijke implicaties van ons onderzoek.

\section{Theoretisch kader}

De sociologische immigratieliteratuur suggereert dat de integratie van migrantgroepen in de ontvangende samenleving bestaat uit integratie in ten minste drie verschillende behoeftedomeinen (Esser, 2003; Fokkema \& De Haas, 2011). Economische integratie verwijst naar de mogelijkheid te studeren, deel te nemen aan de arbeidsmarkt en een inkomen te verdienen waarmee men op zijn minst kan rondkomen. Sociale integratie verwijst naar het bestaan van sociale relaties met mensen binnen, maar vooral ook buiten de eigen etnische groep. Psychische integratie refereert aan de identificatie met de ontvangende samenleving, een gevoel van behoren, gemeenschap en gevoelens van algemeen en politiek vertrouwen. Nederlands onderzoek laat zien dat Nederlandse migranten beperkt geïntegreerd zijn in deze drie domeinen: door werkloosheid of een laag inkomen beschikken zij over beperkte economische hulpbronnen (Van Tubergen, 2006; Hagendoorn et al., 2003), hun sociale netwerk is beperkter, vooral wat betreft de contacten met autochtone Nederlanders en identificatie met 
de ontvangende samenleving en vertrouwen in andere mensen en politieke instituties zijn lager (Dinesen, 2013; Elkins \& Sides, 2007; Martinovic, 2013; Staerklé et al., 2010).

Iedere migrant heeft, zo nemen we aan, de wens te integreren in de verschillende domeinen van de ontvangende samenleving. Integratie kan daarmee gezien worden als een vorm van behoeftebevrediging, terwijl gebrekkige integratie gezien kan worden als een onbevredigde behoefte. De hypothesen met betrekking tot de onderzoeksvragen worden in deze studie dan ook afgeleid vanuit het overkoepelende behoeftebevredigingperspectief. Deze theorie kan een verklaring bieden vanuit de verschillende integratiedomeinen en gaat ervan uit dat het niet kunnen vervullen van menselijke basisbehoeften een belangrijke risicofactor is voor het ontstaan van depressies (Maslow, 1970; Oishi et al., 1999; Veenhoven, 1991). Hoewel bovengenoemde onderzoekers zich bezighielden met motivatie en geluk, trekken wij hun redenering door in onze studie. Depressieklachten zijn immers (mogelijke) psychische uitingsvormen van een gebrek aan geluk en mentaal welbevinden, die tot uiting kunnen komen wanneer menselijke basisbehoeften niet (kunnen) worden vervuld. Hieronder formuleren we per integratiedomein hypothesen over de relatie tussen beperkte integratie en depressieklachten, gebruikmakend van het behoeftebevredigingperspectief.

\subsection{Beperkte psychische integratie en depressieklachten}

In de literatuur over integratiedomeinen wordt psychische integratie veelal omschreven in termen van nationale identificatie (Gordon, 1964; Esser, 2003). Vanuit het migrantenperspectief gaat het om de sterkte van de emotionele betrokkenheid bij de ontvangende samenleving. Een voorbeeld hiervan is de mate waarin een individu de nationale identiteit als een belangrijk onderdeel van zijn persoonlijke identiteit ziet (Verkuyten, 2005). Psychische integratie omvat echter meer dan nationale identificatie. Het gaat ook om de acceptatie van de culturele en institutionele condities van de nationale gemeenschap voor het vormgeven van een prettig leven (Esser, 2001; Heath \& Roberts, 2006). Psychische integratie gaat daarmee over een gevoel van behoren in het ontvangende land dat bestaat uit de acceptatie van anderen in die samenleving en het vertrouwen in andere mensen, maar ook in instituties. Beperkte psychische integratie in de ontvangende samenleving, in termen van een gebrekkige nationale identificatie en gebrekkig vertrouwen in andere mensen en in politieke instituties, kan leiden tot depressieklachten doordat de psychische basisbehoeften niet vervuld worden (Verkuyten, 2005). Dit leidt tot de volgende hypothe- 
se: hoe beperkter de psychische integratie van migranten, hoe meer depressieklachten zij zullen hebben (hypothese 1).

Psychische integratie in de ontvangende samenleving wordt gezien als het moeilijkste aspect, of anders gezegd, het laatste stadium van integratie. Het is niet waarschijnlijk dat het voorkomt voordat er substantiële voordelen worden ervaren in termen van economische en sociale integratie (Alba \& Nee, 1997). Daarom zal bij de bespreking van beperkte economische en sociale integratie ook uitgegaan worden van een indirect effect op depressieklachten via beperkte psychische integratie.

\subsection{Beperkte economische integratie en depressieklachten}

Een gebrekkige economische integratie is een van de belangrijkste verklaringen voor depressieklachten onder migranten. Het gaat hierbij om de mogelijkheid een (goede) opleiding af te ronden en de toegang tot economische hulpbronnen (zoals een rendabel inkomen). Als gevolg van een lagere sociaaleconomische positie hebben migranten minder -en regelmatig onvoldoende- materiële hulpbronnen, waardoor hun economische behoeften minder worden vervuld (Gijsberts, Huijnk \& Dagevos, 2012; Hagendoorn et al., 2003). Onderzoek laat zien dat dit een sterk effect heeft op depressieklachten, mede omdat een gebrek aan deze hulpbronnen moeilijkheden oplevert om te voorzien in basisbehoeften (Cheung \& Leung, 2004; Heady, Muffels \& Wooden, 2004; Moghaddam, 2008). In dit artikel beschouwen we een beperkte economische integratie als het niet deelnemen aan de arbeidsmarkt en het ervaren van economische problemen (zoals bijvoorbeeld geld moeten lenen voor dagelijkse uitgaven).

Beperkte economische integratie heeft daarnaast mogelijk ook een indirect effect op depressieklachten, via een beperkte psychische integratie. Deelname aan de arbeidsmarkt stimuleert een gevoel van prestatie, eigenwaarde en behoren, dat vertaald kan worden in een positieve houding ten aanzien van het ontvangende land en de inwoners (Gordon, 1964). Economisch onsuccesvol zijn, bijvoorbeeld moeite hebben om de eindjes aan elkaar te knopen, geeft mensen daarentegen het gevoel buitengesloten en benadeeld te worden, wat samen kan gaan met minder algemeen en politiek vertrouwen (Heath \& Roberts, 2006). Het ervaren van economische problemen - en daarmee een beperkte economische behoeftebevrediging - zet migranten apart van de meerderheid en ondermijnt hun motivatie om zich aan te passen (Hagendoorn, Veenman \& Vollebergh, 2003) en is, zo veronderstellen wij, geassocieerd met een negatieve evaluatie van de samenleving, haar instituties en de medemens (een beperkte psychische behoeftebevrediging). Hieruit kunnen de volgende hypothesen worden af- 
geleid: hoe beperkter de economische integratie van migranten, hoe meer depressieklachten zij zullen hebben (hypothese 2a), doordat zij psychisch minder zijn geïntegreerd (hypothese $2 \mathrm{~b}$ ).

\subsection{Beperkte sociale integratie en depressieklachten}

Sociale netwerken, sociale ondersteuning en de ervaren kwaliteit van iemands primaire sociale relaties hebben een sterk direct effect op depressieklachten (Diener \& Seligman, 2004; Hooghe \& Vanhoutte, 2011; Kapikiran, 2012; Ram, 2010; Wong et al., 2012). Zo blijkt ervaren eenzaamheid een belangrijke voorspeller van depressieklachten (Kapikiran, 2012). In dit artikel vatten we een beperkte sociale integratie van migranten op als een gebrek aan contacten in het algemeen (algemeen isolement), en specifiek met autochtone Nederlanders (interetnisch isolement) en ervaren eenzaamheid. Migranten hebben vaak vrienden en familie moeten achterlaten in het herkomstland, terwijl sociale banden met de autochtone bevolking gehinderd kunnen worden door culturele barrières en de neiging sociale relaties aan te gaan met soortgelijke mensen. Ook kunnen taalproblemen de mogelijkheid tot het vormen van sociale relaties in de weg staan in de ontvangende samenleving (Martinovic et al., 2009). Als gevolg hiervan lopen migranten een hoger risico op gebrekkige sociale ondersteuning en ook zullen zij mogelijk meer eenzaamheid ervaren. Deze beperkte sociale integratie staat volgens de behoeftebevredigingtheorie in direct verband met depressieklachten.

Ook beïnvloedt een beperkte sociale integratie depressieve klachten mogelijk indirect via een beperkte psychische integratie. Onderzoekers hebben laten zien dat de sociale integratie van migrantengroepen een belangrijke verklaring is voor de mate waarin zij zich identificeren met de ontvangende samenleving (Lubbers et al., 2007). Het belangrijkste argument hiervoor is dat interactie met anderen in sociale netwerken en dan met name met autochtone Nederlanders, bijdraagt aan een gevoel van behoren. Ook zorgen sociale banden voor vertrouwen in anderen. Algemeen vertrouwen komt immers tot stand door participatie in sociale netwerken en interactie met anderen. Dit vertrouwen dat ontstaat vanuit het sociale netwerk werkt ook door in het vertrouwen dat men heeft in maatschappelijke instituties (Nannestad, 2008). Vanuit het idee dat een gebrek aan contacten en het ervaren van eenzaamheid (onvervulde sociale behoeften) leiden tot een zwakkere nationale identificatie en sociaal en institutioneel vertrouwen (onvervulde psychische behoeften), volgen de volgende hypothesen: hoe beperkter de sociale integratie van migranten, hoe meer depressieklachten zij zullen hebben (hypothese 3a) en; hoe beperkter de sociale integratie die 
migranten ervaren, hoe meer depressieklachten zij zullen hebben, doordat zij psychisch minder zijn geïntegreerd (hypothese $3 \mathrm{~b}$ ).

\subsection{Moderatie van beheersingsoriëntatie}

Beheersingsoriëntatie is een term uit de psychologie waarmee de mate wordt aangeduid waarin iemand de oorzaken van wat hem overkomt bij zichzelf of juist buiten zichzelf zoekt (Rotter, 1954). Het is een eigenschap van iemands persoonlijkheid waarin grofweg twee soorten onderscheiden worden. Een interne beheersingsoriëntatie duidt op het idee dat het leven wordt bepaald door de persoon zelf en dat deze persoon zijn of haar leven als maakbaar beschouwt. Mensen met een externe beheersingsoriëntatie ondervinden een gebrek aan controle over het leven: het wordt bepaald door de omgeving, het lot, toeval en andere mensen. In de literatuur wordt dit persoonlijkheidskenmerk geschaard onder de 'coping resources': 'personal characteristics upon which people may draw when dealing with stressors' (Pearlin \& Schooler, 1978). In haar review studie stelt Thoits (1995: p. 6o) dat 'an impressive number of studies show that a sense of control or mastery both directly reduces psychological disturbance and psychical illness and buffers the deleterious effects of stress exposure on psychical and mental health'. In de sociologische literatuur wordt dezelfde beheersingsoriëntatie genoemd als verklaring waarom sommige werklozen minder psychische hinder ondervinden van hun economisch kwetsbare situatie, dan andere werklozen (Nordenmark \& Strandh, 1999).

Ook valt te verwachten dat de directe effecten van beperkte economische, sociale en psychische integratie op depressieklachten bij migranten afhangen van de beheersingsoriëntatie die deze migranten hebben (Johnson \& Sarason, 1978). Een gevoel van hulpeloosheid, het idee dat alles je overkomt en dat je geen grip hebt op gebeurtenissen, zijn risicofactoren op zich voor het ontstaan van depressieklachten (Maier \& Seligman, 1976). Beperkte integratie binnen de verschillende domeinen zal bovendien, volgens onze verwachting, in sterkere mate leiden tot depressieklachten wanneer de migrant problemen ervaart als iets dat buiten de eigen beheersing ligt, dan wanneer het idee overheerst dat de betreffende migrant hier controle over kan uitoefenen (Maier \& Seligman, 1976). Immers, in het laatste geval zal de migrant de situatie als minder problematisch ervaren en meer vertrouwen hebben dat deze door eigen inzet kan worden verbeterd. Dit leidt tot de volgende hypothese: beperkte economische, sociale en psychische integratie zullen sterker tot depressieklachten leiden bij migranten die een meer externe beheersingsoriëntatie hebben dan bij migranten die een meer interne beheersingsoriëntatie hebben (hypothese 4). Figuur 1 geeft een overzicht van de verwachte effecten in modelvorm. 


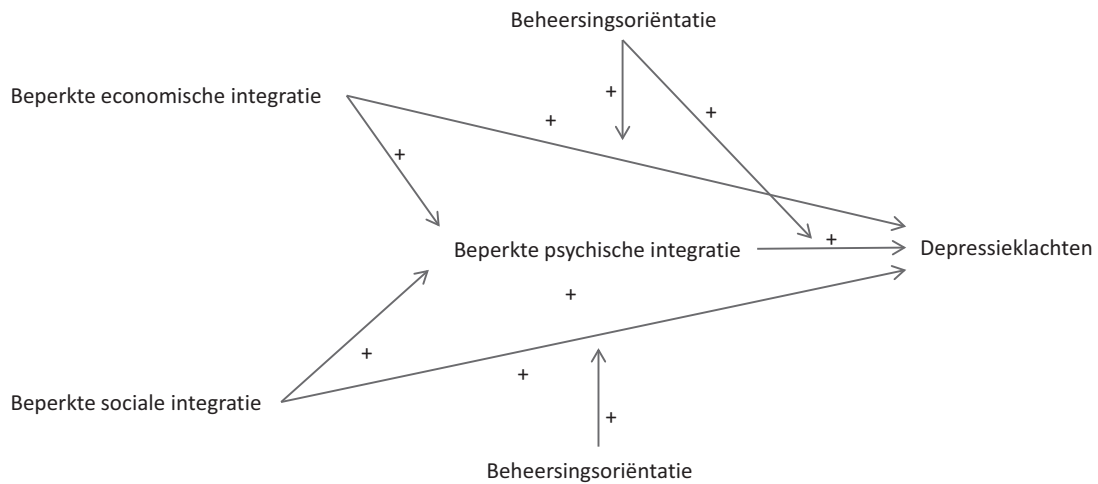

Figuur 1 Theoretisch model voor depressieklachten onder Turkse en Marokkaanse migranten van de eerste generatie

\section{$3 \quad$ Data en operationalisering}

In deze studie worden data gebruikt van de eerste golf van de Nederlandse Levensloopstudie (NELLS, 2010: De Graaf, et al., 2010). Deze data zijn verzameld van 2008 tot 2010 onder etnische minderheidsgroepen en autochtonen in Nederland (14 tot 49 jaar). Voor deze dataverzameling werd gebruikgemaakt van een tweedelige gestratificeerde steekproef. Het eerste deel betrof een aselecte gestratificeerde steekproef van 35 gemeenten naar regio en urbanisatiegraad. Het tweede deel betrof een aselecte gestratificeerde steekproef uit het bevolkingsregister, gebaseerd op leeftijd en geboorteland van de respondenten en van hun ouders. Respondenten van Marokkaanse en Turkse herkomst zijn oververtegenwoordigd. De eerste generatie betreft Turkse en Marokkaanse migranten die niet in Nederland geboren zijn.

De vragenlijst bestond uit een mondeling (face-to-face) gedeelte en een schriftelijk gedeelte dat de respondenten zelf moesten invullen. Het mondelinge gedeelte had betrekking op de sociaaleconomische en sociaaldemografische achtergrond van respondenten. Het schriftelijke gedeelte richtte zich op normen en waarden, houdingen, bekwaamheid en sociale integratie van de respondent. De totale respons was $5^{2}$ procent, wat vergelijkbaar is met soortgelijke surveys in Nederland. Voor Nederlanders was de respons het hoogst ( 56 procent), gevolgd door Turkse migranten (50 procent). De respons was het laagst onder Marokkaanse migranten (46 procent). De lagere respons bij de migrantengroepen wordt veroorzaakt 
doordat zij moeilijker te bereiken waren en bovendien minder vaak bereid waren om mee te werken aan het onderzoek. Daarnaast waren er respondenten die niet deel konden nemen door taalproblemen. In totaal werden er 5312 mensen geïnterviewd. Bij aanvang van de databewerkingen waren gegevens beschikbaar van 1476 Turkse en Marokkaanse migranten (736 Turks en 740 Marokkaans). De overige respondenten zijn verwijderd uit het databestand. Na verwijdering uit de analyse van migranten met ontbrekende gegevens blijven er 1241 over.

\subsection{Afhankelijke variabele: depressieklachten}

Depressieklachten zijn gemeten met de Center for Epidemiologic Depression Scale (CES-D) in het schriftelijke gedeelte van de NELLS-vragenlijst. Deze schaal bestaat oorspronkelijk uit twintig items waarvan er in de NELLS zestien zijn opgenomen. Net als in voorgaand onderzoek zijn vier items uit de originele CES-D schaal, die betrekking hebben op positieve gevoelens, niet gemeten (Harker, 2001). De CES-D schaal is ontwikkeld om symptomen van depressie vast te stellen in surveys voor de algemene bevolking. De respondenten werden onder andere de volgende items voorgelegd: 'In de afgelopen week: bleef ik maar in de put zitten; vond ik mijn leven een mislukking; kon ik maar niet op gang komen'. De antwoordmogelijkheden waren: (1) 'zelden of nooit (minder dan 1 dag)', (2) 'soms of weinig (1-2 dagen)', (3) 'regelmatig (3-4 dagen)' of (4) 'meestal of altijd (5-7 dagen)'. Voor deze zestien items is de gemiddelde score per respondent berekend, indien de respondent op alle items een geldige score had (84,1 procent, dus 1241 respondenten). De schaal met zestien items is volgens Schroevers et al. (2000) een betrouwbare en valide meting van depressieklachten. De items vormen samen één factordimensie (Schroevers et al., 2000) met een eigenwaarde groter dan 1. De interne consistentie van de schaal is zeer goed (Cronbach's alfa is 0,942). In tabel 1 staan de beschrijvende statistieken van deze en andere geconstrueerde variabelen. De scores lopen van 1 tot 4 waarbij een hogere score staat voor meer depressieklachten. Het gemiddelde is 1,4 . De frequentieverdeling van deze variabele (niet gepresenteerd) laat zien dat 72 procent van de migranten niet of nauwelijks depressieklachten heeft, dus 28 procent kampt met enige tot veel depressieklachten. 
Tabel 1 Beschrijvende statistieken

\begin{tabular}{|c|c|c|c|c|c|}
\hline & Percentage & Gemiddelde & $\begin{array}{l}\text { Standaard- } \\
\text { deviatie }\end{array}$ & Minimum & Maximum \\
\hline \multicolumn{6}{|l|}{ Afhankelijke variabele } \\
\hline Depressieklachten & & 1,38 &, 51 & 1 & 4 \\
\hline \multicolumn{6}{|l|}{ Onafhankelijke variabelen } \\
\hline \multicolumn{6}{|l|}{ Beperkte psychische integratie } \\
\hline Nationale disidentificatie & & 2,32 & ,75 & 1 & 5 \\
\hline Algemeen wantrouwen & & 3,30 & 68 & 1 & 5 \\
\hline Politiek wantrouwen & & 2,80 & ,64 & 1 & 4 \\
\hline \multicolumn{6}{|l|}{ Beperkte economische integratie } \\
\hline \multicolumn{6}{|l|}{ Arbeidsmarktpositie } \\
\hline Schoolgaand & 7,70 & & & 0 & 1 \\
\hline Werkend & 59,40 & & & 0 & 1 \\
\hline Niet werkend & 17,20 & & & 0 & 1 \\
\hline (Missende waarden) & 15,80 & & & 0 & 1 \\
\hline Ervaren economische problemen & & 2,12 & 1,42 & 1 & 6 \\
\hline \multicolumn{6}{|l|}{ Beperkte sociale integratie } \\
\hline Algemeen isolement & & 3,22 & 1,19 & 1 & 7 \\
\hline Interetnisch isolement & & 3,49 & 1,56 & 1 & 7 \\
\hline Ervaren eenzaamheid & & 2,05 &, 49 & 1 & 4 \\
\hline \multicolumn{6}{|l|}{ Conditionerende variabele } \\
\hline Externe beheersingsoriëntatie & & 2,10 & 61 & 1 & 4 \\
\hline \multicolumn{6}{|l|}{ Controlevariabelen } \\
\hline Leeftijd & & 34,98 & 7,26 & 14 & 49 \\
\hline \multicolumn{6}{|l|}{ Geslacht } \\
\hline Man & 48,80 & & & 0 & 1 \\
\hline Vrouw & 51,20 & & & 0 & 1 \\
\hline \multicolumn{6}{|l|}{ Huishoudsamenstelling } \\
\hline Alleenstaand & 8,50 & & & 0 & 1 \\
\hline Paar zonder kinderen & 7,20 & & & 0 & 1 \\
\hline Paar met kinderen & 69,70 & & & 0 & 1 \\
\hline Eenoudergezin & 10,40 & & & 0 & 1 \\
\hline (Ontbrekende waarden) & 4,20 & & & 0 & 1 \\
\hline \multicolumn{6}{|l|}{ Opleidingsniveau } \\
\hline Primair & 24,10 & & & 0 & 1 \\
\hline Lager secundair & 25,70 & & & 0 & 1 \\
\hline Hoger secundair & 21,80 & & & 0 & 1 \\
\hline Tertiair & 14,70 & & & 0 & 1 \\
\hline (Ontbrekende waarden) & 13,70 & & & 0 & 1 \\
\hline Ervaren discriminatie & & 1,33 &, 40 & 1 & 3 \\
\hline
\end{tabular}

Bron: Nederlandse Levensloop studie, 2010, N=1241 


\subsection{Intermediërende variabele: beperkte psychische integratie}

Een eerste indicator voor beperkte psychische integratie is nationale disidentificatie. Dit is gemeten met vier items, zoals ' $\mathrm{Ik}$ voel me op mijn plek in de Nederlandse samenleving', en 'Ik voel me verbonden met Nederland'. Er was keuze uit vier antwoordcategorieën lopend van (1) 'zeer mee eens' tot (5) 'zeer mee oneens'. Deze vier items zijn samengenomen tot een gemiddelde score voor nationale disidentificatie als er op tenminste drie items een geldige score was (Cronbach's alfa is 0,863 ). Zoals in tabel 1 te zien is, lopen deze gemiddelde scores van 1 tot 5 waarbij een hogere score staat voor minder nationale identificatie, dus voor beperktere psychische integratie. Het gemiddelde is 2,3. Omdat deze variabele slechts 0,1 procent ontbrekende waarden had, is ervoor gekozen deze ontbrekende waarden het gemiddelde toe te kennen om ze niet uit de analyse te verliezen. De verdeling van de variabele verandert nauwelijks omdat het om zo'n klein percentage gaat.

Een tweede indicator voor beperkte psychische integratie is algemeen wantrouwen. Dit is gemeten aan de hand van drie items, zoals 'Als je anderen helpt, kom je vaak bedrogen uit'. Er was keuze uit vijf antwoordcategorieën lopend van (1) 'zeer mee eens' tot (5) 'zeer mee oneens'. De items zijn gespiegeld zodat voor alle items een hoge score staat voor meer algemeen wantrouwen en zijn vervolgens samengenomen tot een gemiddelde score als er op tenminste twee items een geldige score was (Cronbach's alfa is 0,651$)$. Het gemiddelde is 3,3. De 0,2 procent ontbrekende waarden zijn vervangen met het gemiddelde.

Politiek wantrouwen, tot slot, is gemeten met vier items over hoeveel vertrouwen de respondent heeft in de overheid, politiek, de Europese Unie en politie en justitie. De antwoordcategorieën varieerden van (1) 'heel veel vertrouwen' tot (5) 'heel weinig vertrouwen'. De gemiddelde score is toegekend als er op tenminste drie variabelen een geldige score was. Deze schaal heeft een goede betrouwbaarheid (Cronbach's alfa is 0,822 ). Een hogere score staat voor meer politiek wantrouwen. Het gemiddelde is 2,8 (tabel 1). Slechts 0,3 procent van de migranten had een ontbrekende waarde, dus ook hier zijn deze ingevuld met het gemiddelde.

\subsection{Onafhankelijke variabelen}

Beperkte economische integratie. Een eerste indicator van beperkte economische integratie is de arbeidsmarktpositie van respondenten. Dit is een nominale variabele met drie categorieën, namelijk (1) 'schoolgaand' (2) 'werkzaam' en (3) 'niet werkzaam'. Onder 'schoolgaand' vallen respondenten die voltijd of deeltijd naar school gaan. Onder 'werkzaam' vallen respondenten die nu betaalde arbeid verrichten. Ten slotte vallen responden- 
ten die nu geen betaalde arbeid verrichten, ongeacht of ze dat ooit wel gedaan hebben, onder de categorie 'niet-werkzaam'. Van deze variabele zijn dummy's gemaakt waarbij een extra categorie is toegevoegd voor de ontbrekende waarden $(15,8$ procent $)$.

Een tweede indicator voor beperkte economische integratie is het ervaren van economische problemen. De respondenten werden onder andere de volgende items voorgelegd: 'Heeft $u$ de laatste maanden te maken gehad met: geld lenen voor noodzakelijke uitgaven; moeite hebben met de eindjes aan elkaar te knopen'. De antwoordcategorieën waren (1) 'ja' en (2) 'nee'. Deze variabelen zijn omgecodeerd zodat 'ja' de score 1 en 'nee' de score o kreeg. Vervolgens zijn de scores op deze vijf items bij elkaar opgeteld en bij de totaalscores is 1 opgeteld zodat deze variabele, in overeenstemming met de andere variabelen, begint bij score 1. Deze schaal heeft een goede betrouwbaarheid (Cronbach's alfa is 0,743). Zoals in tabel 1 te zien is, lopen deze scores van 1 tot 6 waarbij een hogere score staat voor meer ervaren economische problemen, dus voor beperktere economische integratie. Het gemiddelde is 2,1. Omdat deze variabele slechts 0,7 procent ontbrekende waarden had, is het gemiddelde toegekend aan deze ontbrekende waarden.

Beperkte sociale integratie. Een eerste indicator voor beperkte sociale integratie is algemeen isolement van familie, vrienden, collega's of medestudenten en buren, ongeacht de etniciteit van deze potentiële netwerkleden. Er is gevraagd hoe vaak de respondent contact heeft met deze mensen. Er was keuze uit 8 antwoordcategorieën lopend van (1) 'bijna elke dag' tot (7) 'nooit' en (8) 'niet van toepassing (heeft deze persoon niet)'. De antwoordcategorieën 'nooit' en 'niet van toepassing' zijn samengenomen omdat deze beide duiden op afwezigheid van contact. Vervolgens zijn deze vier items samengenomen tot een gemiddelde score als er op tenminste drie variabelen een geldige score was. Ondanks dat deze schaal een lage betrouwbaarheid heeft (Cronbach's alfa 0,475), kunnen deze items toch samengevoegd worden om validiteitredenen. Ze slaan immers allemaal op sociale contacten. Door tijdrestricties kan men echter niet met alle mensen contact onderhouden: meer tijdsinvestering in contacten met familie gaat bijvoorbeeld mogelijk niet per se samen met meer contacten met vrienden of collega's, waardoor het in strikte zin geen herhaalde metingen zijn van hetzelfde begrip (wat de lage Cronbach's alfa, wat een betrouwbaarheidsmaat is, verklaart) Een hogere score staat voor meer algemeen sociaal isolement, dus voor beperktere sociale integratie. Het gemiddelde is 3,2 (tabel 1). Deze variabele heeft geen ontbrekende waarden.

De tweede indicator voor beperkte sociale integratie heeft betrekking 
op interetnisch isolement. Waar het bij de eerste indicator ging om contact met mensen ongeacht hun etniciteit, gaat het nu om het hebben van contact met autochtone Nederlanders. Er is gevraagd hoe vaak de respondent contact heeft met mensen van Nederlandse afkomst in de buurt, op werk of school en in verenigingen of clubs. Ook bij deze items was er keuze uit 8 antwoordcategorieën: van (1) 'bijna elke dag' tot (7) 'nooit' en (8) 'niet van toepassing, (heeft deze persoon niet)'. Ook bij deze variabelen zijn de antwoordcategorieën 'nooit' en 'niet van toepassing' samengenomen omdat ze beiden duiden op afwezigheid van contact met autochtone Nederlanders. Vervolgens zijn ook deze items samen genomen tot een gemiddelde score voor interetnisch isolement als er op tenminste twee items een geldige score was. Ondanks dat ook deze schaal een lage betrouwbaarheid heeft (Cronbach's alfa 0,468), kunnen deze items toch samengevoegd worden om soortgelijke validiteitredenen als hierboven genoemd. Een hogere score staat voor meer interetnisch isolement, dus voor beperktere sociale integratie. Het gemiddelde is 3,5 (tabel 1). De o,6 procent ontbrekende waarden zijn ingevuld met het gemiddelde.

Om ervaren eenzaamheid te meten kregen de respondenten zes items voorgelegd, zoals: 'Ik ervaar een leegte om me heen', 'Er zijn genoeg mensen op wie ik in geval van narigheid kan terugvallen' en 'Vaak voel ik me in de steek gelaten'. Er was keuze uit vier antwoordcategorieën lopend van (1) 'helemaal van toepassing' tot (4) 'helemaal niet van toepassing'. Drie items zijn gespiegeld zodat voor alle items een hoge score staat voor meer ervaren eenzaamheid. Deze zes items zijn samengenomen tot een gemiddelde score voor eenzaamheid als er op tenminste vier items een geldige score was. Deze schaal heeft een redelijke tot goede betrouwbaarheid (Cronbach's alfa is 0,748 ). Het gemiddelde is 2,1 (tabel 1 ). De migranten (0,2 procent) met een ontbrekende waarde hebben het gemiddelde toegekend gekregen.

\subsection{Conditionerende variabele: beheersingsoriëntatie}

De respondenten kregen vijf items voorgelegd die hun beheersingsoriëntatie meten, zoals 'Ik heb weinig controle over de dingen die mij overkomen' en 'Soms voel ik dat ik een speelbal van het leven ben' (van 'helemaal van toepassing' (1) tot 'helemaal niet van toepassing' (4)). Deze vijf items zijn gespiegeld zodat een hogere score staat voor een meer externe beheersingsoriëntatie en vervolgens is de gemiddelde score (2,1: tabel 1) op de vijf items berekend, mits er op tenminste drie items een geldige score was. Deze variabele heeft geen ontbrekende waarden. 


\subsection{Controlevariabelen}

We nemen vijf controlekenmerken mee, namelijk ervaren discriminatie, sekse, leeftijd, opleidingsniveau en huishoudsamenstelling. Omdat sekse een categorische variabele is ((1) 'man' en (2) 'vrouw'), is hiervoor een dummy gemaakt. Leeftijd (16-49 jaar) is een intervalvariabele. Er zijn geen ontbrekende waarden op deze twee controlevariabelen.

De respondenten kregen zes items voorgelegd over ervaren discriminatie op verschillende domeinen, zoals bij het solliciteren naar een baan, op het werk of bij uitgaansgelegenheden. Er was telkens keuze uit drie antwoordcategorieën: (1) 'nee, nooit', (2) 'ja, enkele keer' en (3) 'ja, redelijk vaak'. Deze zes items zijn samengenomen tot een gemiddelde score als er op tenminste vier items een geldige score was. Deze schaal heeft een goede betrouwbaarheid (Cronbach's alfa is 0,811 ). Het gemiddelde is 1,3 (tabel 1 ). Slechts 1,1 procent had een ontbrekende waarde. Voor hen is het gemiddelde toegekend.

Om het hoogst bereikte opleidingsniveau van een respondent te bepalen, is uitgegaan van de hoogste voltooide opleiding, ongeacht of het hier een opleiding uit het herkomstland of in Nederland betrof. Van de respondenten die momenteel nog een opleiding volgen, is de hoogst bereikte opleiding gelijkgesteld aan het huidige opleidingsniveau. Uiteindelijk bestaat deze variabele uit vier categorieën: (1) 'primair' (2) 'lager secundair' (3) 'hoger secundair' en (4) 'tertiair'. Hiervoor zijn dummy's gemaakt waarbij een extra categorie is opgenomen voor de ontbrekende waarden $(13,7$ procent). Respondenten zonder opleiding of met basisonderwijs vallen in de categorie primair opleidingsniveau. Respondenten met lbo, vmbo, mavo of kort mbo vallen in de categorie 'lager secundair'. Respondenten met havo, vwo of lang mbo vallen in de categorie 'hoger secundair'. Respondenten vallen in de categorie 'tertiair' als ze een hbo-opleiding of universitaire opleiding hebben gevolgd of als ze gepromoveerd zijn.

Huishoudsamenstelling is een nominale variabele met antwoordcategorieën (1) 'alleenstaand' (2) 'paar zonder kinderen' (3) 'paar met kinderen' en (4) 'eenoudergezin'. Ook hiervoor zijn dummy's gemaakt waarbij een extra categorie is opgenomen voor de ontbrekende waarden (4,2 procent). Ook van de controlevariabelen zijn de beschrijvende statistieken opgenomen in tabel 1. 


\section{$4 \quad$ Analyse en resultaten}

\subsection{Toetsing van directe effecten en mediatiehypothesen}

Om de onderzoeksvragen te kunnen beantwoorden zijn er multivariate lineaire regressieanalyses uitgevoerd waarvan de resultaten zijn opgenomen in tabel 2a. Het eerste model toont de directe effecten van de twee indicatoren van beperkte economische integratie, en de drie indicatoren van beperkte sociale integratie op depressieklachten. In model twee worden de drie mediatievariabelen van beperkte psychische integratie toegevoegd. In beide modellen zijn daarnaast alle controlevariabelen opgenomen.

Tabel 2a Lineaire regressieanalyse van 'depressieklachten'

\begin{tabular}{|c|c|c|c|c|c|c|c|}
\hline & Model 1 & \multicolumn{2}{|c|}{ Model 2a } & \multicolumn{2}{|c|}{ Model $2 b$} & \multicolumn{2}{|c|}{ Model 2c } \\
\hline & B & B & Beta & B & Beta & B & Beta \\
\hline Constante & 148 & 140 & & 093 & & ,059 & \\
\hline \multicolumn{8}{|l|}{ Beperkte economische integratie } \\
\hline Arbeidsmarktpositie (werkend=ref.) & & & 149 & & 149 & & , 149 \\
\hline Schoolgaand &, $143^{* *}$ &, $143^{* *}$ & &, $143^{* *}$ & &, $150^{* *}$ & \\
\hline Niet-werkend &,$- 105^{* *}$ &,$- 106^{* *}$ & &,$- 106^{* *}$ & &,$- 102^{* *}$ & \\
\hline $\begin{array}{l}\text { Ontbrekend } \\
\text { arbeidsmarktpositie }\end{array}$ &, $122^{* *}$ &, $123^{* *}$ & &, $122^{* *}$ & &, $124^{* *}$ & \\
\hline Ervaren economische problemen &, $065^{* * *}$ &, $065^{* * *}$ & , 184 &, $064^{* * *}$ & , 180 &, $063^{* * *}$ & , 178 \\
\hline \multicolumn{8}{|l|}{ Beperkte sociale integratie } \\
\hline Algemeen isolement &, 012 &, 012 & 027 & ,012 &, 029 & 012 & 028 \\
\hline Interetnisch isolement &,- 002 &,- 002 & ,006 &,- 002 &, 007 &,- 003 & ,009 \\
\hline Ervaren eenzaamheid & $381^{* * *}$ &, $380^{* * *}$ & ,370 &, $378^{* * *}$ & ,368 &, $380^{* * *}$ & ,369 \\
\hline \multicolumn{8}{|l|}{ Beperkte psychische integratie } \\
\hline Nationale disidentificatie & & 006 & ,009 & & & & \\
\hline Algemeen wantrouwen & & & & 019 &, 026 & & \\
\hline Politiek wantrouwen & & & & & &, $040^{*}$ & 050 \\
\hline Leeftijd & ,002 & ,002 & & ,002 &, 029 & ,002 & 029 \\
\hline Geslacht & & & 143 & & 143 & & , 145 \\
\hline (man=ref.) & & & & & & & \\
\hline Vrouw &, $145^{* * *}$ &, $145^{* * *}$ & &, $146^{* * *}$ & &, $146^{* * *}$ & \\
\hline
\end{tabular}




\begin{tabular}{|c|c|c|c|c|c|c|c|}
\hline & Model 1 & \multicolumn{2}{|c|}{ Model 2a } & \multicolumn{2}{|c|}{ Model $\mathbf{2 b}$} & \multicolumn{2}{|c|}{ Model $2 c$} \\
\hline & B & B & Beta & B & Beta & B & Beta \\
\hline Huishoudsamenstelling & & & 102 & & 103 & & 103 \\
\hline (paar zonder kinderen = ref.) & & & & & & & \\
\hline Alleenstaand &,- 019 &,- 019 & &,- 017 & &,- 021 & \\
\hline Paar met kinderen &,- 082 &,- 082 & &,- 081 & &,- 083 & \\
\hline Eenoudergezin & 055 & ,056 & & ,057 & &, 057 & \\
\hline Ontbrekend &, 062 & 061 & & ,068 & & ,062 & \\
\hline huishoudsamenstelling & & & & & & & \\
\hline Opleidingsniveau & & & ,042 & & ,044 & & 044 \\
\hline (primair = ref.) & & & & & & & \\
\hline Lager secundair &,- 024 &,- 024 & &,- 024 & &,- 024 & \\
\hline Hoger secundair &,- 019 &,- 018 & &,- 018 & &,- 020 & \\
\hline Tertiair &, 040 &, 040 & & ,043 & & ,043 & \\
\hline $\begin{array}{l}\text { Ontbrekend } \\
\text { opleidingsniveau }\end{array}$ &,- 017 &,- 017 & &,- 018 & &,- 017 & \\
\hline Ervaren discriminatie &, $133^{* * *}$ &, $132^{* * *}$ & , 104 &, $133^{* * *}$ & 105 &, $123^{* * * *}$ & 097 \\
\hline Gecorrigeerde $R^{2}$ & 282 & 281 & & 282 & & 283 & \\
\hline
\end{tabular}

Wat betreft beperkte economische integratie was de verwachting dat naarmate migranten beperktere economische integratie ervaren, zij meer depressieklachten zullen hebben (hypothese 2a). De eerste indicator van beperkte economische integratie, arbeidsmarktpositie, ondersteunt deze verwachting niet. Niet-werkende migranten hebben significant minder depressieklachten dan werkende migranten. Dat is tegenstrijdig met wat verwacht werd. De tweede indicator van beperkte economische integratie, ervaren economische problemen, ondersteunt de verwachting wel. Naarmate migranten meer economische problemen ervaren, hebben zij inderdaad significant meer depressieklachten. Hypothese 2a wordt, kortom, deels ondersteund door de resultaten. Voor beperkte sociale integratie was de verwachting dat naarmate migranten beperkter sociaal geïntegreerd zijn, zij meer depressieklachten zullen hebben (hypothese 3a). De effecten van algemeen en interetnisch sociaal isolement zijn niet significant en ondersteunen daarmee deze verwachting niet. De derde indicator van beperkte sociale integratie, ervaren eenzaamheid, ondersteunt de verwachting wel. Migranten die meer eenzaamheid ervaren, hebben inderdaad significant meer depressieklachten. Hypothese $3^{a}$ wordt dus deels ondersteund door de resultaten. ${ }^{2}$

Het tweede model $^{3}$ geeft de indirecte effecten weer van beperkte eco- 
nomische integratie, beperkte sociale integratie en van ervaren discriminatie op depressieklachten via beperkte psychische integratie. Voor elke indicator van beperkte psychische integratie is een deelmodel opgenomen. Model 2a bevat de mediatie van nationale disidentificatie, model $2 \mathrm{~b}$ bevat de mediatie van algemeen wantrouwen en model $2 \mathrm{c}$ bevat de mediatie van politiek wantrouwen.

De verwachting was dat naarmate migranten beperktere psychische integratie ervaren, zij meer depressieklachten hebben (hypothese 1). De resultaten in modellen $2 \mathrm{a}$ en $2 \mathrm{~b}$ laten zien dat nationale disidentificatie en algemeen wantrouwen niet significant samenhangen met depressieklachten. De resultaten in model 2c laten zien dat naarmate migranten meer politiek wantrouwen hebben, zij meer depressieklachten ervaren. Het effect van deze derde indicator van beperkte psychische integratie is in tegenstelling tot de andere twee indicatoren wel significant. Hypothese 1 wordt dus deels ondersteund door de resultaten.

Daarnaast werd verwacht dat beperkte economische integratie en beperkte sociale integratie leiden tot meer depressieklachten, omdat deze migranten beperktere psychische integratie ervaren (respectievelijk hypothesen $2 b$ en $3 b$ ). Uit een aanvullende analyse op de eerste indicator van beperkte psychische integratie, nationale disidentificatie, blijkt dat algemeen sociaal isolement, interetnisch isolement en ervaren eenzaamheid, significant positieve effecten hebben op nationale disidentificatie. Maar doordat nationale disidentificatie geen significant effect heeft op depressieklachten, kunnen de mediaties via deze indicator van beperkte psychische integratie niet plaatsvinden.

Uit een aanvullende analyse op de tweede indicator van beperkte psychische integratie, algemeen wantrouwen, blijkt dat ervaren economische problemen, interetnisch isolement en ervaren eenzaamheid significante positieve effecten hebben op algemeen wantrouwen. Echter, algemeen wantrouwen heeft geen significant effect op depressieklachten, dus ook hier kan beperkte psychische integratie niet als mediërend mechanisme fungeren. Bovendien zien we dat alle directe effecten in deze modellen (2a en 2 b) nagenoeg gelijk zijn aan de effecten zoals weergegeven in model 1 zonder mediatievariabelen.

Zoals we geconstateerd hadden, heeft de derde indicator van beperkte psychische integratie, politiek wantrouwen, wel een significant (positief) effect op depressieklachten. Uit een aanvullende analyse blijkt dat ervaren economische problemen en interetnisch isolement significant positieve effecten hebben op politiek wantrouwen. Wanneer we de resultaten wat betreft beperkte economische integratie uit model $2 \mathrm{c}$ vergelijken met de 
resultaten uit model 1 zonder mediaties, zien we dat de effecten van arbeidsmarktpositie en ervaren economische problemen nagenoeg gelijk zijn gebleven. Hier is dus geen sprake van mediatie. Wanneer we de resultaten wat betreft beperkte sociale integratie uit model $2 \mathrm{c}$ vergelijken met de resultaten uit model 1 zonder mediaties, zien we dat de effecten van algemeen en interetnisch isolement en van ervaren eenzaamheid ook vrijwel identiek zijn.

$\mathrm{Al}$ met al concluderen we dat er geen mediaties plaatsvinden van nationale disidentificatie, algemeen wantrouwen en politiek wantrouwen. De mediatiehypothesen $(2 \mathrm{~b}$ en $3 \mathrm{~b}$ ) worden niet ondersteund worden door de resultaten.

Omdat niet alle predictoren een even sterk effect hebben op depressieklachten, bespreken we het relatieve belang van de predictoren in het eindmodel (model 2a, 2b en 2c). Voor de intervalvariabelen worden daartoe de zogenaamde beta's gebruikt zoals die in tabel 2a vermeld staan bij elke predictor. Voor de nominale variabelen (dummy's) worden zogenaamde sheaf-variabelen geconstrueerd omdat de beta's van de losse categorieën niet vergelijkbaar zijn met de beta's van intervalvariabelen (Heise, 1972). De sheaf-variabelen zijn geconstrueerd door de producten van de categorieën met bijbehorende b-coëfficiënten uit tabel 2a te sommeren (voorbeeld: sheafarbeidsmarktpositie $=, 143^{*}$ schoolgaand,$+- 105^{*}$ nietwerkend,$+ 122^{*}$ ontbrekendarbeidsmarktpositie). De beta's van deze sheaf-variabelen zijn wel vergelijkbaar met die van de intervalvariabelen. Hoe hoger de beta van de variabele, hoe beter de variabele een voorspeller is van depressieklachten.

In het eindmodel is ervaren eenzaamheid (beperkte sociale integratie) duidelijk de sterkste voorspeller van depressieklachten (beta rond ,369). Ervaren economische problemen en arbeidsmarktpositie (beperkte economische integratie) zijn tamelijk sterke predictoren (beta's respectievelijk rond ,181 en 149) maar die zijn nog niet half zo sterk als de predictor ervaren eenzaamheid. Geslacht en ervaren discriminatie zijn matige voorspellers van depressieklachten (beta's respectievelijk rond ,143 en ,104). Politiek wantrouwen (beperkte psychische integratie) blijkt een zwakke voorspeller van depressieklachten te zijn (beta is ,050). De overige variabelen hebben geen significant effect op depressieklachten, waarmee hun belang klein is.

\subsection{Toetsing van de moderatiehypothese}

De vierde en laatste hypothese heeft betrekking op de verwachting dat beperkte economische, sociale en psychische integratie sterker zullen lei- 
den tot depressieklachten bij migranten die een meer externe beheersingsoriëntatie hebben, dan bij migranten die een meer interne beheersingsoriëntatie hebben. De resultaten zijn weergegeven in tabel $2 b$ (en bijbehorende figuren 2 tot en met 6 ). Naast de bespreking van het gemiddelde effect van de beheersingsoriëntatie, zullen de interacties gezamenlijk worden besproken.

In model 3 zien we dat naarmate migranten een meer externe beheersingsoriëntatie hebben, zij meer depressieklachten hebben. De bijbehorende beta is 0,17 , wat aangeeft dat het belang van beheersingsoriëntatie ongeveer gelijk is aan het belang van het ervaren van economische problemen. Dit is een eerste indicatie dat de interactiehypothese ondersteund zou kunnen worden door de resultaten. Model 4 is opgedeeld in vijf submodellen waarin telkens één interactieterm is opgenomen. Hoewel deze submodellen alle variabelen bevatten van beperkte economische en sociale integratie, ervaren discriminatie en de controlevariabelen, zijn alleen de effecten weergegeven die relevant zijn voor de interactiehypothese in het betreffende model. De interactie-effecten van arbeidsmarktpositie (beperkte economische integratie), nationale disidentificatie (beperkte psychische integratie) en algemeen wantrouwen (beperkte psychische integratie) zijn niet in de tabel weergegeven, omdat de verschillen tussen migranten met een interne en externe beheersingsoriëntatie niet significant zijn.

Tabel 2b Lineaire regressieanalyse van 'depressieklachten'

\begin{tabular}{|c|c|c|c|c|c|c|}
\hline & Model 3 & Model 4a & Model 4b & Model 4c & Model 4d & Model 4e \\
\hline & B & B & B & B & B & B \\
\hline Constante &, 034 & ,190 &, $444^{* *}$ &, $407 * *$ & $1,262 * * *$ &, $666 * *$ \\
\hline \multicolumn{7}{|c|}{ Beperkte economische integratie } \\
\hline \multicolumn{7}{|c|}{ Arbeidsmarktpositie (werkend=ref.) } \\
\hline Schoolgaand &, $126 *$ & & & & & \\
\hline Niet-werkend &,$- 122 * * *$ & & & & & \\
\hline $\begin{array}{l}\text { Ontbrekend } \\
\text { arbeidsmarktpositie }\end{array}$ &, $096 *$ & & & & & \\
\hline Ervaren economische problemen &, $058 * * *$ &,- 011 & & & & \\
\hline \multicolumn{7}{|l|}{ Beperkte sociale integratie } \\
\hline Algemeen isolement &, 012 & &,$- 114^{* *}$ & & & \\
\hline Interetnisch isolement &,- 002 & & &,$- 100 * * *$ & & \\
\hline Ervaren eenzaamheid &, $323 * * *$ & & & &,$- 273 * * *$ & \\
\hline
\end{tabular}




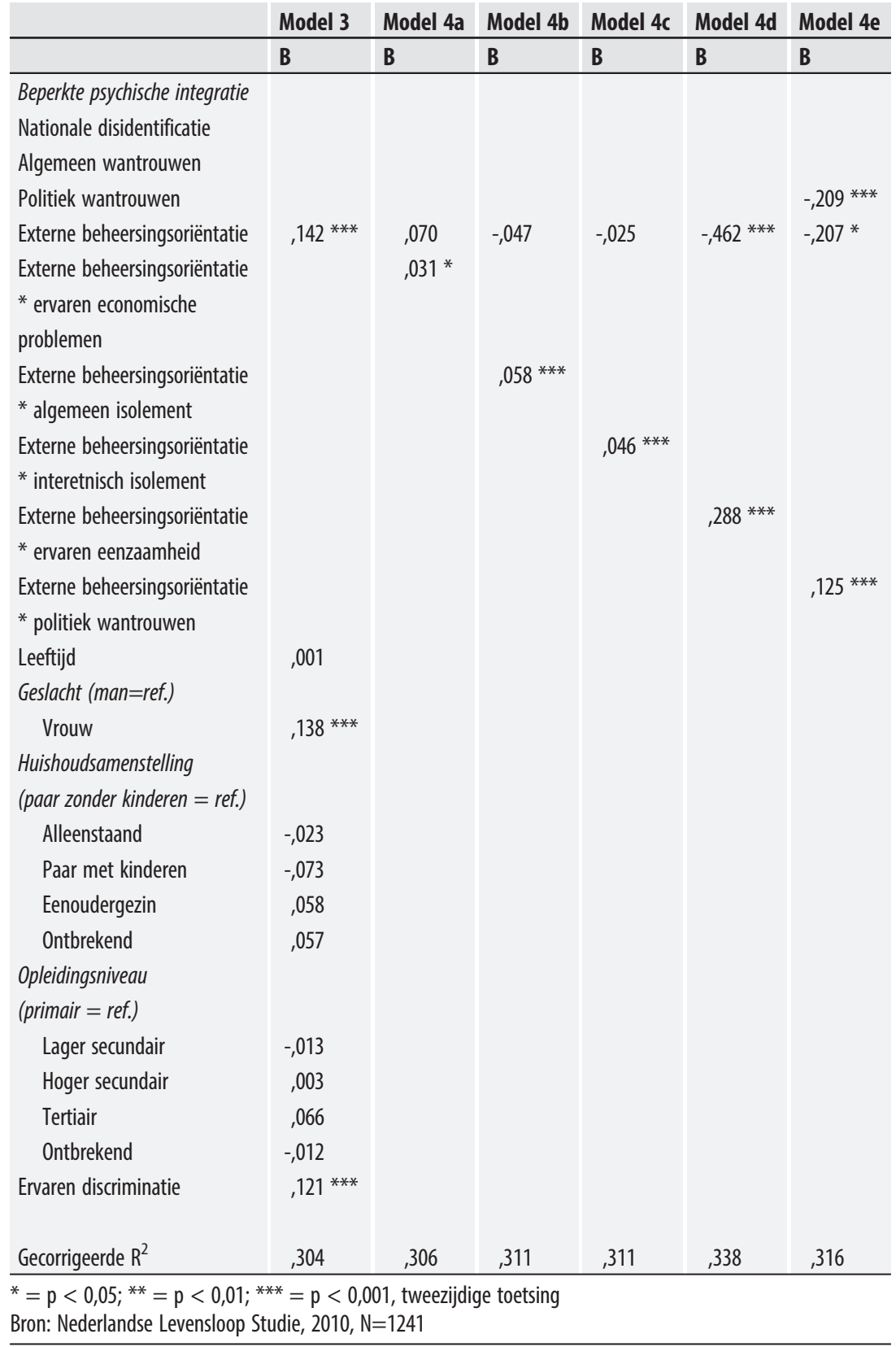




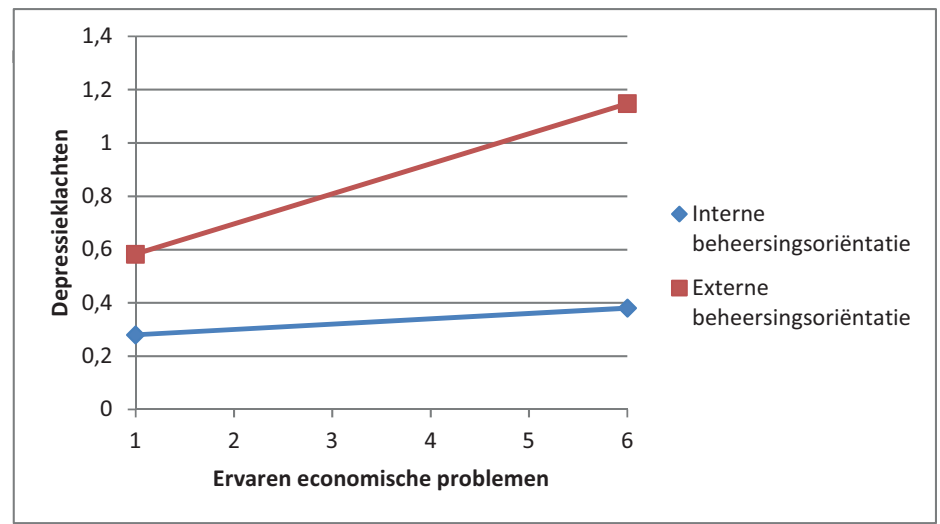

Figuur 2 Interactie met ervaren economische problemen

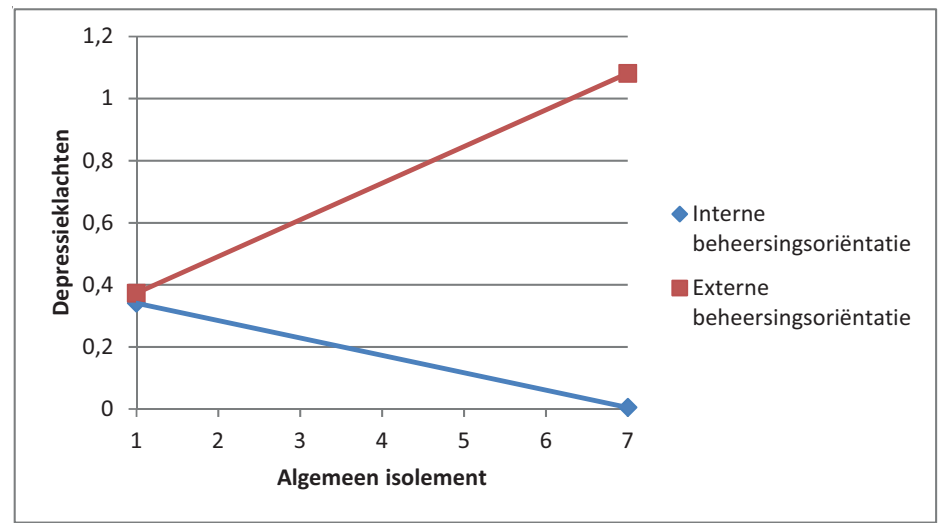

Figuur 3 Interactie met algemeen isolement

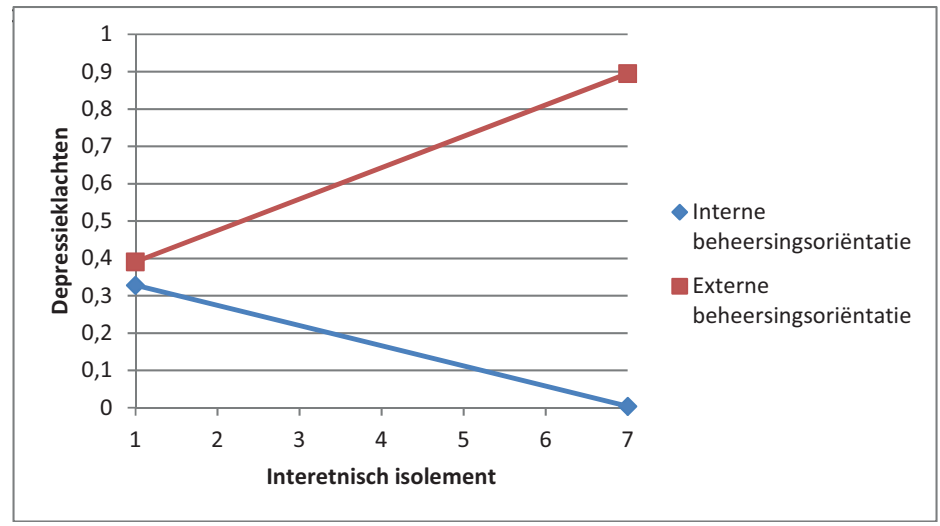

Figuur 4 Interactie met interetnisch isolement 


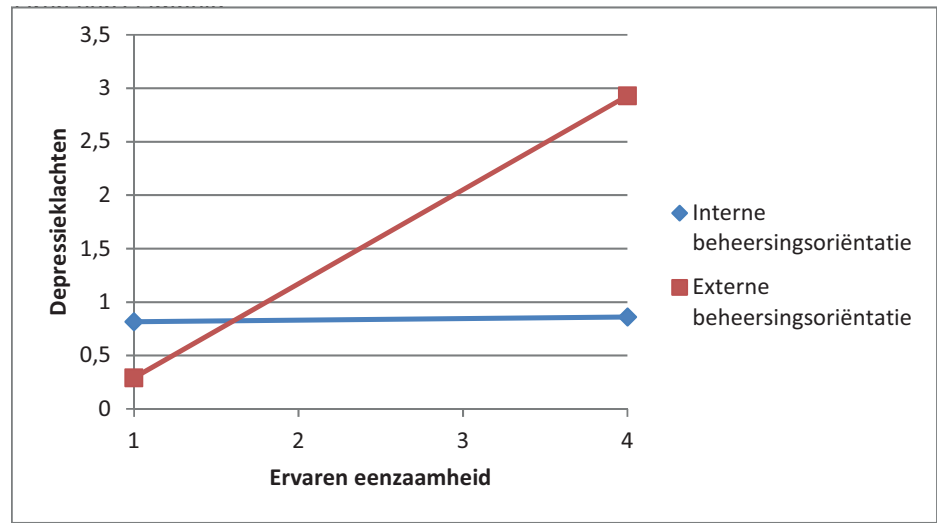

Figuur 5 Interactie met ervaren eenzaamheid

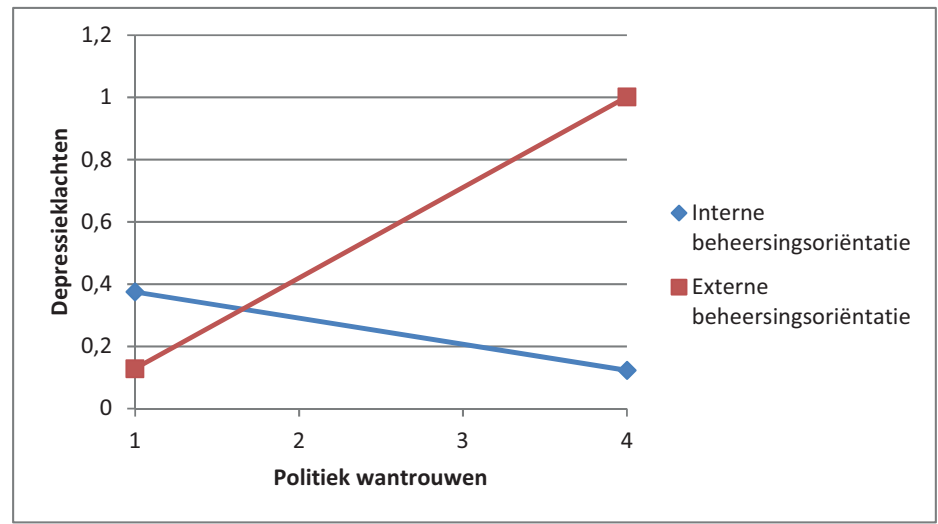

Figuur 6 Interactie met politiek wantrouwen

We zien ten eerste (model 4a) dat het ervaren van economische problemen sterker leidt tot depressieklachten wanneer migranten een meer externe beheersingsoriëntatie hebben. Figuur $2^{4}$ laat zien dat migranten met een externe beheersingsoriëntatie, ongeacht hun ervaren economische problemen, meer depressieklachten hebben dan migranten met een interne beheersingsoriëntatie. Bovendien zien we dat het effect van ervaren economische problemen sterker is voor migranten met een externe beheersingsoriëntatie. Ten tweede zien we (Model $4 b$, figuur 3 ) dat algemeen isolement sterker leidt tot depressieklachten wanneer migranten een meer externe beheersingsoriëntatie hebben. Migranten met een externe beheersingsoriëntatie ervaren, ongeacht algemeen isolement, meer depressieklachten dan migranten met een interne beheersingsoriëntatie. Dit verschil in depressieklachten is klein bij weinig algemeen isolement en groot bij veel algemeen isolement, omdat algemeen isolement bij migranten met 
een externe beheersingsoriëntatie tot meer depressieklachten leidt. Interetnisch isolement, ten derde (model 4c, figuur 4) leidt sterker tot depressieklachten wanneer migranten een meer externe beheersingsoriëntatie hebben. Figuur 4 geeft hetzelfde beeld voor interetnisch isolement als figuur 3 voor algemeen sociaal isolement. Ervaren eenzaamheid (model $4 d$, figuur 5), ten vierde, leidt sterker tot depressieklachten wanneer migranten een meer externe beheersingsoriëntatie hebben: het positieve effect van ervaren eenzaamheid is veel zwakker bij migranten met een interne beheersingsoriëntatie dan bij migranten met een externe beheersingsoriëntatie. Ook voor politiek wantrouwen (model 4e, figuur 6), tot slot, blijkt dat het effect op depressieklachten sterker is wanneer migranten een meer externe beheersingsoriëntatie hebben. ${ }^{6}$

Al met al kunnen we concluderen dat de interactiehypothese grotendeels bevestigd wordt. We zien bij ervaren economische problemen, bij de drie indicatoren van beperkte sociale integratie en bij politiek wantrouwen dat beperkte economische, sociale en psychische integratie sterker leiden tot depressieklachten bij migranten met een externe beheersingsoriëntatie dan bij migranten met een interne beheersingsoriëntatie.

\section{Conclusie en discussie}

Eerder onderzoek heeft uitgewezen dat met name Turkse en Marokkaanse migranten in Nederland een groter risico lopen op depressieklachten dan autochtone Nederlanders. Dit onderzoek had als doel om een bijdrage te leveren aan de verklaring van depressieklachten onder Turkse en Marokkaanse Nederlanders van de eerste generatie en richtte zich op de invloed van beperkte economische, sociale en psychische integratie en op de (modererende) rol van beheersingsoriëntatie. Voor dit onderzoek is gebruik gemaakt van lineaire regressiemodellen die zijn gebaseerd op cross-sectionele data van NELLS 2010.

De centrale onderzoeksvraag van dit artikel luidde: 'in hoeverre gaan beperkte economische, sociale en psychische integratie samen met depressieklachten bij Turkse en Marokkaanse Nederlanders van de eerste generatie?'. Ter beantwoording van deze vraag gebruikten we diverse indicatoren binnen de domeinen. De resultaten leiden niet tot een eenduidige conclusie: niet deelnemen aan de arbeidsmarkt gaat niet samen met meer depressieklachten, maar het ervaren van economische problemen (niet rond kunnen komen bijvoorbeeld) wel; migranten die door het gebrek aan (interetnische) contacten meer in een sociaal isolement verkeren, ver- 
tonen niet meer depressieklachten dan migranten met meer contacten, maar het ervaren van eenzaamheid gaat wel samen met meer depressieklachten, en tot slot; depressieklachten zijn onafhankelijk van een gebrek aan identificatie met Nederland en wantrouwen in de medemens, maar migranten die weinig institutioneel vertrouwen hebben, rapporteren meer psychische problemen dan migranten met meer institutioneel vertrouwen.

Een beperkte integratie in ieder domein gaat daarmee gepaard met meer depressieklachten, maar niet ieder domein is even belangrijk. De sterkste voorspeller van depressieklachten bleek het ervaren van eenzaamheid. Deze vorm van sociaal isolement bleek een twee maal zo sterke predictor te zijn als het ervaren van economische problemen, terwijl een beperkte integratie in het psychische domein relatief onbelangrijk bleek. Als we dit verbinden aan het behoeftebevredigingperspectief - het niet kunnen vervullen van menselijke basisbehoeften is een belangrijke risicofactor voor het ontstaan van depressies - dan wijst dit erop dat vooral het gevoel te kunnen terugvallen op mensen om je heen en je geen zorgen te hoeven maken om rond te kunnen komen van belang zijn. Het zijn klaarblijkelijk deze basisbehoeften die migranten vaak ontberen, die onder hen depressieve gevoelens aanwakkeren.

Met ons onderzoek poogden we ook vooruitgang te boeken door de vraag te beantwoorden in hoeverre de invloed van beperkte economische en sociale integratie op depressieklachten wordt verklaard door psychische integratie. Psychische integratie wordt vaak beschouwd als de finale fase: pas wanneer economische en sociale behoeften van migranten in de ontvangende samenleving in voldoende mate worden bevredigd, zullen zij zich identificeren met dat land en vertrouwen hebben in de medemens en maatschappelijke instituties. De resultaten wezen echter uit dat migranten die economisch en/of sociaal beperkt geïntegreerd zijn, niet meer depressieklachten vertonen omdat ze zich minder identificeren met Nederland en minder algemeen en institutioneel vertrouwen hebben. Waar het gaat om de samenhang met depressieklachten, functioneren de drie domeinen onafhankelijk van elkaar. Tezamen met de bevinding dat vooral het ervaren van eenzaamheid en economische problemen sterke voorspellers zijn van depressieklachten, is de implicatie dat beleid gericht op het voorkomen of tegengaan hiervan, waarschijnlijk het meest effectief is.

Tot slot stelden wij de vraag in hoeverre de invloed van beperkte economische, sociale en psychische integratie verschilt tussen groepen met een meer interne of meer externe beheersingsoriëntatie. De achtergrond van deze vraag was dat de wijze waarop migranten in het leven staan en de mate waarin zij het gevoel hebben controle te kunnen uitoefenen op hun 
situatie, waarschijnlijk van belang is voor de manifestatie van depressiegevoelens. Veel migranten bevinden zich in het ontvangende land in stressvolle economische en sociale situaties. Juist bij een gevoel van hulpeloosheid en machteloosheid (een externe beheersingsoriëntatie) vertalen deze stressvolle situaties zich mogelijk in een minder mentaal welbevinden. Voor 5 van de 8 indicatoren van een beperkte integratie bleek dit, ten eerste, het geval: voor het ervaren van economische problemen, algemeen sociaal isolement, interetnisch isolement, ervaren eenzaamheid en politiek wantrouwen. Ten tweede bleek de beheersingsoriëntatie tevens een zelfstandige invloed uit te oefenen op depressieklachten: migranten met een externe oriëntatie rapporteren gemiddeld meer depressieklachten dan migranten met een interne oriëntatie. Bovendien bleek de invloed ook substantieel. Het belang is vergelijkbaar met het ervaren van economische problemen.

Dit onderzoek heeft te kampen met het methodologische nadeel dat door het gebruik van cross-sectionele data geen sterk bewijs aangevoerd kan worden voor causaliteit van de gevonden relaties. Depressieklachten kunnen ontstaan uit een beperkte integratie en het gevoel geen controle te hebben over het leven. Andersom kunnen depressieklachten ook in de weg staan van integratie en het gevoel invloed te hebben op de situatie in het ontvangende land. Dit causaliteitsprobleem noopt ons de bevindingen met de nodige voorzichtigheid te benaderen en suggereert dat onze resultaten gerepliceerd zouden moeten worden in longitudinale studies.

Wat vast staat is dat de integratie van migranten en hun kinderen in de samenleving een belangrijk onderwerp van publieke bezorgdheid en politiek debat is. Politici betogen dat een gebrek aan integratie van migranten geld kost, een gebrek aan loyaliteit jegens het gastland weerspiegelt en de cohesie in de samenleving ondermijnt. Er lijkt consensus te zijn dat integratie voordelig is voor migranten en voor de samenleving als geheel. Dat beperkte integratie nadelig is voor migranten zelf, heeft dit onderzoek laten zien door de relatie te leggen met het ervaren van depressieklachten. Onze belangrijkste bevindingen tezamen werpen licht op de migranten die het meest kwetsbaar zijn: migranten die moeilijk rond kunnen komen, eenzaamheid ervaren en het gevoel hebben geen controle te hebben over hun leven. Dit gevoel van een gebrek aan controle versterkt de invloed van economische problemen en eenzaamheid op het ervaren van depressieklachten.

Voor politici en beleidsmakers is de boodschap niet nieuw dat het cruciaal is voor migranten om een volwaardige economische positie te bekleden en terug te kunnen vallen op mensen in hun netwerk. Bovendien blijkt 
wat dit laatste betreft dat de hoeveelheid van contacten, of ze nu binnen de eigen groep zijn of daarbuiten, niet zo belangrijk is. Het gaat om het gevoel mensen in je omgeving te hebben die er voor je zijn. De beleidstendens om te bezuinigen op allerlei vormen van sociale zekerheid, gezondheidszorg en op het faciliteren van sociale participatie, of het nu gaat om algemeen beleid of beleid gericht op etnische minderheden, heeft mogelijk geleid tot meer en sterkere economische en sociale problemen, wat volgens deze studie depressieklachten in de hand werkt. Een nieuw inzicht is dat de beheersingsoriëntatie van migranten ook een belangrijke rol speelt. Migranten zullen bij aankomst verschillen in hun gevoel controle te hebben op de nieuwe situatie in het ontvangende land. Maar voor een deel is dit gevoel mogelijk ook te beïnvloeden, door migranten (meer dan nu) bij te staan, te begeleiden in de samenleving met haar instituties en te coachen. Gezien de problemen die migranten zelf ervaren als gevolg van depressieklachten en de maatschappelijke kosten die daarmee zijn gemoeid, lijkt het zinvol om ook het bevorderen van een interne beheersingsoriëntatie onder migranten onderdeel te maken van het integratiebeleid.

\section{Noten}

1. We laten derhalve de vergelijking met autochtone Nederlanders en met de tweede generatie achterwege. De tweede generatie heeft meer contact met autochtone Nederlanders dan de eerste generatie (Gijsberts \& Dagevos, 2009) en identificeert zich meer met de ontvangende samenleving dan met de etnische herkomst van de ouders (Tolsma, Lubbers \& Gijsberts, 2012). Hiermee is een beperkte integratie in domeinen van de ontvangende samenleving meer van toepassing op migranten van de eerste generatie.

2. Voor de controlevariabelen laten de resultaten zien dat naarmate migranten meer discriminatie ervaren, zij significant meer depressieklachten hebben. Verder heeft alleen geslacht een significant effect op depressieklachten: vrouwen hebben significant meer depressieklachten dan mannen. Tevens hebben we onderzocht of er verschillen zijn in depressieklachten tussen Turkse en Marokkaanse migranten. Dit bleek niet het geval, zowel bij bivariate toetsing, als bij opname van een dummy in model $2 \mathrm{c}$ in tabel 2a.

3. Op basis van het eindmodel ( $2 \mathrm{a}, 2 \mathrm{~b}$ en $2 \mathrm{c})$ kan geconcludeerd worden dat er geen sprake is van multicollineariteit waarbij predictoren elkaar teveel overlappen (VIFwaarden liggen rond 1). Alle variabelen in het eindmodel tezamen verklaren 28,2 procent van de variantie van depressieklachten.

4. De begin- en eindpunten van de lijnen in figuur 2 tot en met 6 zijn berekend door de regressievergelijking in te vullen met de laagste en hoogste waarden van beheersingsoriëntatie (respectievelijk 1: intern, en 4: extern) en met de laagste en hoogste waarde van de betreffende indicator voor beperkte integratie, in dit geval ervaren economische problemen (respectievelijk 1 en 6).

5. Men zou kunnen beargumenteren dat de effecten van beperkte integratie op depressie- 
klachten sterker zijn bij mensen met een interne dan met een externe beheersingsoriëntatie, omdat ze de problemen dan immers bij zichzelf zoeken. Het gaat bij beheersingsoriëntatie echter meer om het idee van machteloosheid en hulpeloosheid (extern) versus het idee de touwtjes in handen te hebben (intern).

6. Opvallend is de bevinding dat voor migranten met een interne beheersingsoriëntatie, een gebrek aan (interetnische) contacten en een hogere mate van politiek wantrouwen samengaat met minder depressieklachten (zie figuren 3, 4 en 6). Inhoudelijk is dit lastig te verklaren. Het gaat hier om een kleine en waarschijnlijk selectieve groep migranten met weinig (interetnische) contacten en sterk institutioneel wantrouwen, die mede door hun interne beheersingsoriëntatie per definitie weinig depressieklachten vertonen. De geobserveerde daling in de lijnen is dan ook mild en mogelijk gebaseerd op toeval. Tezamen met de eerder besproken bevinding dat algemeen sociaal isolement, interetnisch isolement en politiek wantrouwen (relatief) onbelangrijke voorspellers zijn van depressieklachten, lijkt een inhoudelijke duiding van deze bevindingen dan ook niet zoveel toe te voegen. De observatie dat een beperkte integratie, vooral voor eenzaamheid en economische problemen, het sterkst samengaat met depressieklachten voor migranten met een externe beheersingsoriëntatie, is de belangrijkste.

\section{Literatuur}

Aichberger, M.C., Schouler-Ocak, M., Mundt, A., Busch, M.A., Nickels, E., Heimann, H.M., Ströhle, A., Reischies, F.M., Heinz, A. \& Rapp, M.A. (2010). Depression in middle-aged and older first generation migrants in Europe: Results from the Survey of Health, Ageing and Retirement in Europe (SHARE). European Psychiatry, 25, 468-475.

Alba, R. \& Nee, V. (1997). Rethinking assimilation theory for a new era of immigration. International Migration Review, 31, 826-874.

Berry, J.W. (1997). Immigration, acculturation, and adaption. Applied Psychology: An International Review, 46, 5-68.

Berry, J.W. (2005). Acculturation: Living successfully in two cultures. International Journal of Intercultural Relations, 29, 697-712.

Cheung, C. \& Leung, K. (2004). Forming life satisfaction among different social groups during the modernization of China. Journal of Happiness Studies, 5, 23-56.

Diener, E.F. \& Seligman, M.E.P. (2004). Beyond money: Toward an economy of well-being. Psychological Science in the Public Interest, 5, 1-31.

Dinesen, P.T. (2013). Where you come from or where you live? Examining the cultural and institutional explanation of generalized trust using migration as a natural experiment. European Sociological Review, 29, 114-128.

Elkins, Z. \& Sides, J. (2007). Can institutions build unity in multiethnic states? American Political Science Review, 101, 693-708.

Esser, H. (2001). Integration und etnische schichtung. Mannheim: Arbeitspapiere-Mannheimer Zentrum für Europäische Sozialforschung.

Esser, H. (2003). What substance is there in the term 'Leitkultur'? In: Cuperus, R., Duffek, K.A. \& Kandel, J. (Eds.) The challenge of diversity. Innsbruck: Studienverslag, 47-58.

Fokkema, T. \& Haas, H. de, (2011). Pre-and post-migration determinants of socio-cultural integration of African immigrants in Italy and Spain. International Migration, doi: 10.1111/j.14682435.2011.0068.x (Online gepubliceerd: 3 mei 2011). 
Gijsberts, M. \& Dagevos, J. (2009). Jaarrapport integratie 200g. Den Haag: Sociaal en Cultureel Planbureau.

Gijsberts, M., Huijnk, W. \& Dagevos, J. (2012). Jaarrapport integratie 2011. Den Haag: Sociaal en Cultureel Planbureau.

Gordon, M.M. (1964). Assimilation in American Life. London: Oxford University Press.

Graaf, P.M. de, Kalmijn, M., Kraaykamp, G. \& Monden, C.W.S. (2010). Design and content of the NEtherlands Longitudinal Lifecourse Study (NELLS). Research report. Tilburg University \& Radboud University Nijmegen, Netherlands.

Hagendoorn, L. \& Pepels, J. (2003). Why the Dutch maintain more social distance from some ethnic minorities than others: A model explaining the ethnic hierarchy. In: Hagendoorn, L., Veenman, J. \& Vollebergh, W. (Eds.) Integrating immigrants in the Netherlands: Cultural versus socio-economic integration. Aldershot: Ashgate, 41-61.

Harker, K. (2001). Immigrant generation, assimilation, and adolescent psychological well-being. Social Forces, 79, 969-1004.

Heady, B., Muffels, R. \& Wooden, M. (2004). Money doesn't buy happiness... Or does it? A reconsideration based on the combined effects of wealth, income and consumption. IZA Discussion paper No. 1218. Bonn: Institut zur Zukunft der Arbeit.

Heath, A. \& Robers, J. (2006). British identity: Its sources and possible implications for civic attitudes and behaviour. Oxford: University of Oxford.

Heise, D. (1972). Employing nominal variables, induced variables, and block variables in path analyses. Sociological Methods and Research, 1, 147-173.

Hooghe, M. \& Vanhoutte, B. (2011). Subjective well-being and social capital in Belgian communities. The impact of community characteristics on subjective well-being indicators in Belgium. Social Indicators Research, 100, 17-36.

Johnson, J.H. \& Sarason, I.G. (1978). Life stress, depression and anxiety: internal-external control as a moderator variable. Journal of Psychosomatic Research, 22, 205-208.

Kapikiran, Ș. (2012). Loneliness and life-satisfaction in Turkish early adolescents: The mediating role of self-esteem and social support. Social Indicators Research, doi: 10.1007/s11205-012-0024$\mathrm{x}$ (Online gepubliceerd: 21 maart 2012).

Koneru, V.K., Weisman de Mamani, A.G., Flynn, P.M. \& Betancourt, H. (2007). Acculturation and mental health: Current findings and recommendations for future research. Applied and Preventive Psychology, 12, 76-96.

Kooiker, S.E. (2011). Nederlanders aan het woord over gezondheid en gezond leven: Achtergrondrapport bij de Volksgezondheid Toekomstverkenning 2010. Van gezond naar beter. Rijksinstituut voor Volksgezondheid en Milieu (RIVM).

Lubbers, M.J., Molina, J.L. \& McCarty, C. (2007). Personal networks and ethnic identifications the case of migrants in Spain. International Sociology, 22, 721-741.

Maier, S.F. \& Seligman, M.E. (1976). Learned helplessness: Theory and evidence. Journal of Experimental Psychology, 105, 3-46.

Martinovic, B. (2013). The interethnic contacts of immigrants and natives in the Netherlands: A two-sides perspective. Journal of Ethnic and Migration Studies, 39, 69-85.

Martinovic, B., Tubergen, F. van \& Maas, I. (2009). Dynamics of interethnic contact: A panel study of immigrants in the Netherlands. European Sociological Review, 25, 303-318.

Maslow, A.H. (1970). Motivation and personality. New York: Harper \& Row.

Missine, S. \& Bracke, P. (2012). Depressive symptoms among immigrants and ethnic minorities: A population based study in 23 European countries. Social Psychiatry Psychiatric Epidemiology, 47, 97-109.

Moghaddam, M. (2008). Happiness, faith, friends and fortune: Empircal evidence from the 1998 US survey data. Journal of Happiness Studies, 9, 577-587. 
Nannestad, P. (2008). What have we learned about generalized trust, if anything? Annual Review of Political Science, $11,413-436$.

Nordenmark, M. \& Strandh, M. (1999). Towards a sociological understanding of mental wellbeing among the unemployed: The role of economic and psychological factors. Sociology, 33, $577-597$.

OECD (2014). Mental health and work: Netherlands. Paris: OECD Publishing.

Oishi, S., Diener, E.F., Lucas, R.E. \& Suh, E.M. (1999). Cross-cultural variations in predictors of life satisfaction: Perspectives from needs and values. Personality and Social Psychological Bulletin, 25, 980-990.

Pearlin. L.L. \& Schooler, C. (1978). The structure of coping. Journal of Health and Social Behavior, 19, 2-21.

Ram, R. (2010). Social capital and happiness: Additional cross-country evidence. Journal of Happiness Studies, 11, 409-418.

Rotter, J. (1954). Social learning and clinical psychology. Englewood Cliffs, NJ: Prentice Hall.

Schroevers, M.J., Sandman, R., Sonderen, van E. \& Ranchor, A.V. (2000). The evaluation of the Center for Epidemiologic Studies Depression (CES-D) scale: Depressed and positive affect in cancer patients and healthy reference subjects. Quality of Life Research, 9, 1015-1029.

Selten, J.P., Laan, W., Kupka, R., Smeets, H.M. \& Os, van J. (2012). Risk of psychiatric treatment for mood disorders and psychotic disorders among migrants and Dutch nationals in Utrecht, The Netherlands. Social Psychiatry Psychiatric Epidemiology, 47, 271-278.

Staerklé, C., Sidanius, J., Green, E.G.T. \& Molina, L.E. (2010). Ethnic minority-majority asymmetry in national attitudes around the world: A multilevel analysis. Political Psychology, 31, 491-519.

Thoits, P.A. (1995). Stress, coping, and social support processes: Where are we? What next? Journal of Health and Social Behaviour, 35, 53-79.

Tolsma, J., Lubbers, M. \& Gijsberts, M. (2012). Education and cultural integration among ethnic minorities and natives in the Netherlands: A test of the integration paradox. Journal of Ethnic and Migration Studies, $38,793-813$.

Tubergen, F. van (2006). Immigrant integration: A cross-national study. New York: LFB Scholarly Publishing LLC.

Veenhoven, R. (1991). Is happiness relative? Social Indicators Research, 24, 1-34.

Verkuyten, M. (2005). The social psychology of ethnic identity. Hove: Psychology Press.

Virta, E., Sam, D.L. \& Westin, C. (2004). Adolescents with Turkish background in Norway and Sweden: A comparative study of their psychological adaption. Scandinavian Journal of Psychology, 45, 15-25.

Wit, M.A.S. de, Tuinebreijer, W.C., Dekker, J., Beekman, A.T.F., Gorissen, Schrier, A.C., W.H.M., Penninx, B.W., Komproe, I.H., \& Verhoeff, A.P. (2008). Depressive and anxiety disorders in different ethnic groups. A population based study among native Dutch, and Turkish, Moroccan and Surinamese migrants in Amsterdam. Social Psychiatry and Psychiatric Epidemiology, 43, 905-912.

Wong, W.K.F., Chou, K. \& Chow, N.W.S. (2012). Correlates of quality of life in new migrants to Hong Kong from mainland China. Social Indicators Research, 107, 373-391.

Wurff, F.B. van der, Beekman, A.T.F., Dijkshoorn, H., Spijker, J.A., Smits, C.H.M., Stek, M.L. \& Verhoeff, A.P. (2004). Prevalence and riskfactors for depression in elderly Turkish and Moroccan migrants in the Netherlands. Journal of Affective Disorders, 83, 33-41.

Zeijl, E. (red.) (SCP) (2002). Rapportage Jeugd 2002. Den Haag: Sociaal en Cultureel Planbureau. 


\section{Over de auteurs}

Ellen Bekker is student Sociologie aan de Radboud Universiteit Nijmegen. Dit artikel is gebaseerd op haar Bachelorthesis.

Maurice Gesthuizen is Universitair Docent Sociologie aan de Radboud Universiteit Nijmegen. 
